\title{
Effect of Internal Audit on Expenditure Control in Mubi North Local Government Area
}

\author{
Babbuli Ibrahim Mohammed
}

Dept of Banking and Finance, Adamawa State University Mubi, Nigeria

\begin{abstract}
This study examines the effect of internal audit on expenditure control in Mubi North Local Government Area. This study employed the survey research design. From the population of the study 50 staffs were selected as a sample for this study. The instrument used for collecting data from the respondents is the questionnaire. The data gathered from the respondents was analyzed using simple percentage statistics and hypothesis was tested using chi-square. The finding shows internal audit in Mubi North LGA is very ineffective. This is because internal audit is not carry out effectively, internal audit has significant effect on expenditure control and among the factors militating affecting the effectiveness of internal audit in Mubi North LGA, low quality of staff is the most importance factor. The study therefore, recommends that there is need for top management of LGA to give high priority to internal audit, by putting in place strategies that will lead to effective practice of internal audit among the staff of the LGA which in turn will lead to effective expenditure control.
\end{abstract}

Keywords: Audit, control, effect, expenditure \& internal

\section{INTRODUCTION}

The public sector is present in the economic life in various ways. There is no market economy in which the public sector is not meant to be more or less present, directly or indirectly, between factors influencing and orienting the economic operators. The progress of events linked to this field (the passing from the communist system to a market economy) has implicitly changed the control activity as well, the consultancy and insurance of the activity of public institutions. Internal auditor is part of the management team compare with external auditors who are from outside the organisation. The independent appraisal function established by the management of organisation to review of the internal control system. The unit should be independent in terms of budget, programme of work, reporting mechanism, and adequate staffs and competent to be able to perform their function effectively (Kagashe, 2008).

Aquaisua (2004), defined auditing as an independent checking and investigation of the books of accounts and voucher of a business with a view to enabling the auditor to report, whether the financial statement is properly drown up, so as to show true and fair view of the state of the affairs and the profit (or loss) of the business according to the best of the information and explanations obtained by the auditor and that they comply with the rules laid down by Statement of Standard Accounting Practice (SSAP), and other statutory regulations.

Auditing as a profession arose primarily because of separation in the ownership as well as the administration of a business enterprise. The owners of a business (shareholders) pool their resources together for the purpose of establishing an enterprise, with a common goal of making profit or otherwise. These shareholders may not be available for the day-to-day administration of the enterprise hence the need to appoint professional manager, whose main responsibility is to utilized the shareholders fund effectively. The manager is expected to prepare an account that is a 
quantitative statement stating how the shareholders resources were utilized during a period being referred to as accounting year; this statement is referred to as stewardship account. In other to make the owner of the business place reliance on members of management as regard the true and fair view of the financial statement, the shareholders will appoint an auditor.

Internal audit is an integral part of the finance structure of the public sector organizations. Asare (2009) argues that internal auditing in the public sector it is well structured and it is given the required mandate to perform, improve performances and serve as valuable resource in promoting good governance. The profitability of an enterprise is to a large extent dependent of expenditure control. This is because, the higher the expenditure, the lower the profitability and vice versa. Internal auditing is an important instrument of expenditure control in organization. Therefore, this study examines the effect of internal audit on expenditure control in Mubi North LGA.

The internal audit function in public service faces a lot of challenges, difficulties, and perceptions and to some extent a credibility problems which hamper their activities. Sometimes auditors are seen by management as threat to the organization and therefore the necessary corporation and support are not given them to carry out their mandate. The money voted for them to carry out their duty at the financial year is woefully inadequate and logistics they need from the management are very difficult to get them.

Internal auditors are not seen as partners in developmental agenda of government but rather fault funders and this perception does not motivate internal auditor to execute their work effectively. In addition to these problems public service are measured by three key factors which are effectiveness, efficiencies and economy. However, most of public service organizations are not able to achieve these objectives upon all the resources at their disposal. The auditor's report of government exposes financial embezzlements, misappropriations and misapplication of public money every year. The quality of service provided by some public service to citizens leave much to be desired. Most people see public service as government property and needed attention is not given.

These unfortunate situations forced the public to ask whether internal auditors are actually in this organization and what measures are they putting in place to prevent such menace. Concerned are also raised as to action the parliament is taking to ensure those who commit this act are brought to book to face the full rigor of the law and if possible all the property they have use the nation resources to acquire for themselves are sold to state. There is no doubt that integrity of internal auditor and cordial relationship and support of management and shareholders can promote image of the organization and eliminate wasteful use of nation resources so as to get value for money. From the ongoing there is the need to determine the impact of internal audit unit on the control of expenditure in the local system of government. study;

The following questions guided the

i. What is the extent of effectiveness of internal audit in Mubi North LGA?

ii. What is the extent of compliance with expenditure guidelines in Mubi North LGA? iii. What is the extent to which internal audit affects expenditure control in Mubi North LGA?

iv. What is the factors militating against internal audit effectiveness in impacting expenditure control in Mubi North LGA?

In order to achieve the main objective of the study, the study formulated the following null hypothesis:

$\mathbf{H}_{\mathbf{0}}$ : Internal audit has no significant effect on expenditure control in Mubi North LGA.

\section{LITERATURE REVIEW}

\section{Meaning and Nature of Internal Audit}

The Consultative Council of the Accountancy Bodies (CCAB, 2012), defined an audit as the independent 
examination of, and expression of opinion on the financial statements of an enterprise by an appointed auditor in pursuance of that appointment and in compliance with any relevant statutory obligation. The statement adds that the responsibility for the preparation of the financial statement and the presentation of the information includes therein rests with the management of the enterprises (in the case of a company, the directors). Concept of internal audit, the Chattered Institution of Management Accounting CIMA official terminology defines internal audit as "an independent appraisal activity established within an organization as a service to it". It is a control which functions by examining and evaluating the adequacy and effectiveness of other controls. Internal audit, these are conducted by an employee of a business in to any aspect of its affairs. These employees are called internal auditors. Those being appointed by the management in Nigeria firms are not necessary accountants by training and inclination (Adeniyi, 2004).

William (2003) defined internal audit as an independent appraisal activity within an organization set for the review of operation and as service to management, it is a form of management control which function by measuring and evaluating the effectiveness of other controls. Although, the nature of work required that the auditor shall be given an element of independent while engage in it. The internal auditors differ completely from the statutory auditor. Auditors employed by individual companies, government agencies; partnerships, individuals and other entities are called Internal Auditor's. In major corporations, internal audit staff may be very large, and the director of internal auditing is usually a major job title within the entity.

The institute of internal auditors (IIA) is the primary organization supporting internal auditors; its mission is to be "the primary International Professional Association organized on a worldwide basis, dedicated to the promotion and development of the practice of internal auditing". Internal audit helps an organization accomplish its objectives by bringing a systematic discipline approach to evaluate and improve the effectiveness of risk management, control and governance processes, internal audit review the reliability and integrity of information, compliance with policies and regulations the safeguarding of resources, and established operational goals and objectives audits encompass financial activities and operations including systems, productions engineering, marketing and human resources (William, 2003).

Internal audit is an additional safeguard for proper financial control in the public sector (Badara, 2012). The internal audit is responsible for the audit of all financial transactions by carrying out a continuous examination of all accounting books and records maintained in the organisation with a view to checking or detecting fraud and correcting errors. It is concerned with the examination of the system and procedures in place to ensure their conformity with the regulation as well as the adequate system of internal control.

\section{Purpose of Internal Audit}

Internal auditor is charge with the responsibility of safeguarding the assets and liability of the local government. Services that will enhance the efficiency and effectiveness of the operations of the local government through reviewing of accounting systems, reviewing of internal control systems, reviewing of the implementation of the corporate policies plan and procedures and possibly through carrying out special investigation assigned by the local government.

\section{Internal Audit Administration}

Okon (2003) opined that there are inbuilt safeguards to control local government council finances. In the first place the Chairmen of local government are not signatories to local government cheques. Secondly the independence of the finance committee from the spending committee 
allows it to approach matters concerning local government with detachment and honesty. Thirdly local government is statutorily required to appoint a treasurer whose office must be held separately from the clerks and other officers of the local government. This independent ensures that he approaches his duties with the professional detachment that it requires. All monies of the local government are they payments or receipts must be made through the treasurer.

The status of the treasurer is as high as other chief officers of the local government. This ensures that he cannot be intimidated in to unlawful disbursement of funds belonging to the local government by anybody. There are standing orders for entering in to contracts to ensure that such contracts are not used as avenues for siphoning local government funds. The electorate within the local government area reserves the right to demand and inspect records and minutes of local government meetings and may raise question over any matter. Of course, the role of the internal auditor cannot be undermined.

There is need for minimum supervision, monitoring and control of local government activities and finances in particular for enhanced efficiency and effectiveness; this supervision will enhance the internalization of the culture of public probity and accountability. It will also encourage the maintenance of minimum standards in the provision of amenities nationwide (Okon, 2003).

\section{The Legal Framework of Auditing at the Local Government Level}

The operations of internal auditors at the local government level are governed by certain financial authorities and legal instrument (Adams, 2004). These include the civil service reforms, financial legislations.

\section{a. The Civil Service Reforms}

The civil service reform 1998 provides that there shall be established in each local government an internal audit headed by a qualified accountant to provide a complete and continuous audits of the accounts and records of revenue, expenditure, plan allocated and unallocated where applicable notwithstanding, the existence of an internal audit unit in a local government. The individual officer's responsibilities shall subsist and departmental check shall continue. The internal audit of each local government shall directly be responsible to the accounting officer and the auditor General of the local government councils, and therefore he shall report monthly to the accounting officer as well as accountant general of the local government council on the true position of the audit. He shall also issue special report, if necessary where in his opinion the attention of the auditor general of the local government should be drawn.

\section{b. The Financial Legislations}

Financial legislation especially the audit Act of 1956 set out the basis of internal audit at the local government level. It also provides the instrument of financial regulation which is the financial memoranda for the local government which set out the total financial regulation at the local government level. The Act specifically requires every local government to have an internal audit unit. The financial memoranda provide guidelines for budgeting expenditure control and accounting frame for local government which the internal auditor is to ensure adherence to. The financial memoranda for local government specifies the formal approval of the annual estimate by the council constituted the legal authority for expenditure to be incurred but such general sanction for expenditure procedures for the control of expenditure as contain in (chapter 13 of the financial memoranda). The local government therefore requires all officer responsible for expenditure to exercise due economy. Money must be spent merely because it has been voted. Before any expenditure is committed by all spending department/ officers, it is mandatory that the cash flow 
analysis rendered by the treasurer to the executive committees must be strictly adhered to.

\section{Expenditure Control}

An audit cost money and local government do not spend money any how they expect some benefits to flow from such expenditure. By advantages of an audit, it means the benefits to enjoy by local government; their books of accounts have been audited. It is required that as the action plan of the local government therefore, all activities must geared towards realization of those objectives. It should be noted at this point that no variations are allowed as soon as the budget is approved except and until a supplementary budget is prepared and approved (Okon, 2003).

Public funds are common wealth which must be protected from misuse by public officers (Ayala \& Giancarlo 2006). This means that no funds can be withdrawn from the public funds without the approval of the legislature except those expenditures specifically approved to be charged against the relevant funds by the constitution or the appropriation act or law. The release of funds to meet the day-to-day business of governance, the chief executive must seek the approval of the parliament via an appropriation bill only once in a year. The passing of this bill which automatically means a legislative approval of the chief executive's application transforms the bill into an appropriation act or law.

\section{Types of Local Government Expenditure} Local expenditure is broadly classified in to two (2): Recurrent expenditure and capital expenditure. Recurrent expenditure is expenditure or services and structures that continuous to reflect in local government administration from year to year (Abubakar, 1993). Examples of this are personnel costs (salaries, allowance etc. of workers) and overhead costs (maintenance of vehicles, stationeries, telephone and postal services etc.). capital projects are new and on-going projects or purchases that will require fresh capital outlay and which could last over a period of time (Allen and Unwill, 1974), example of these are infrastructure like boreholes, constructions of roads, fertilizer procurement, vehicle purchase etc.

The types of expenditure item under these sectors are:

i. Economic sector: example, Agric and rural development, livestock, forestry, fisheries, manufacturing, rural electricification e.t.c.

ii. Area development sectors: water resources and water supply, environmental sewage and drainage, town and country planning, community development.

iii. Administrative sector: General administration (office building), staff housing workshop.

iv. Social sectors: these include health, education and social welfare. This expenditure could be in the area of construction of clinic roads, etc. If many however be observed that the types of expenditure and amount expended depends on the size of the local government, their location (either urban or rural), the complexity of the job and as in community development, the contribution to be made by the community. Also in local government, these projects are contracted out.

\section{Internal Audit and Expenditure Control}

Akpa (2008) stated that, the key internal audit and expenditure control mechanisms established in the Nigerian fund accounting system aimed at controlling public funds are: Fund release warrants; Clearance mandates; Departmental vote expenditure account; The voucher system, and Audit Report Quality. Fund Release Warrants: Because of the need to protect public funds from reckless tampering, no withdrawal is allowed from any of the public funds unless so authorized by the Minister/Commissioner for Finance via the instrumentality of the spending warrants. Mandates or remittances are clearances issued by the Accountant-General to authorize release of funds from the CRF, 
DF, and other public funds. While these clearances are called mandates at the federal level, they are referred to as direct remittances at the state level. Furthermore, while the federal mandates are issued to the Central Bank of Nigeria, the state remittances are issued to the main Treasury for payment of capital projects and commercial banks for payment of recurrent expenditures, e.g., monthly salaries, pensions and overhead costs. That is to say that a remittance is a transfer of money from the Treasury to a sub-treasury to pay individuals, e.g., contractors for capital projects and to commercial banks to pay recurrent expenditures. This is to say that the mandates/remittances are of two types: recurrent expenditure and capital expenditure (Abu \& Abdullah, 2010).

A payment voucher (PV) is a verified claim as being a proper charge on the fiscal entity. Every payment from a government unit's vote must be vouched for on a specially prepared form called payment PV which is typically made out in favour of the beneficiary otherwise known as the payee (Okwu, 2012).

\section{Impact of Internal Audit on Expenditure Control}

Have the potential to improve control while delivering resources benefits. Support the director finance assurance in the annual letter of presentation to the auditor general that internal controls are balanced against and proportional to the risk which the mitigates align local government practices with applicable treasury board direction whereby accounts are to be verified in a costs effective manner (Anyakwu, 2010).

Local government has opportunities to improve the efficiency of expenditure processing. The quality assurance processes represent an opportunity to use resources currently processing transactions more effectively to add value to the expenditure process and strengthen financial management at local government. Implementing the following recommendations will guide the department toward a risk-based and more cost effective process:

i. Local government should design and implement a risk-based approach for expenditure authorization once designed it should be formalized in policy and procedures.

ii. Local government should document current expenditure processes and controls to use as a base line for developing a complaint and cost effective risk based process.

iii. A quality assurance plan to guide the process should be developed, communicated, implemented and reported upon.

iv. A system wide monitoring and reporting process should be developed to enable a high degree of assurance surrounding the payment process, and to support the reliability of expenses reported in the financial statements.

v. Management should clearly understand that only the director finance has the right to determine the position level that will be delegated financial authority. All cases of appropriate delegation of authority should be rectified immediately. Finance should implement appropriate controls to ensure that this situation does not reoccur (Adams, 2005).

Some useful information and tools exist that could be used in developing process control maps. For example policies relevant to account verification were easily accessible from the finance site of local government. Local government account verification policies include a checklist for employees who had been delegated authority. The expenditure process, however, has not been documented. A documented process provides the necessary information to understand "where were at" and facilitated the determinates of inquired changes to get to be" there are several other opportunities provided by documenting the process and controls including: Identifying key control points which would help Local government move to a mature system of 
testing controls as opposed to testing transactions, revealing non-value added activities, redundant steps and bottlenecks that could be quickly remedied, identifying the stages in the process where data can be collected and used for decision making, establishing performance measures and targets, consistently applying process and reducing the need for individual employees to develop their own tools and memory aids, developing and communicating an understanding of the overall process and training staff involved in the process (Anyakwu, 2010).

\section{Importance of Internal Audit in the Public Sector}

It is now widely accepted that internal audit unit is necessary for survive of any organisation because of creating good performance to the public. This is because, the work of the internal audit unit is evaluated by examining how they are able to detect and prevent errors within the organisation. However, efficiency of the Internal Audit Unit and effective internal control structure is evidence of good corporate governance as well as competitive advantage of the organisation (Mulinda, 2010).

Internal control system (as a major responsibility of internal audit unit) is affected by business environment. The effectiveness of the internal control system depends on the size of the company and nature of the organisation, that is, if it is fast growing or not (Noorvee, 2006). It is easier to develop a good internal control system in smaller size organisation due to less personnel, more personal contact and less administration whereas on the fast growing organisation the lack of effective internal control system might become an issue in future. On the other hand, however, there are studies that indicate obstacles facing Internal Audit unit in organisation, which leads to the weakness of the internal control system on ensuring financial management.

Their major findings includes; lack of proper independence, lack of professional proficiency thus fails to comply with general standards, lack of capacity such staff and resources in kind and lack of expertise and experience (Badara, 2012; Unegbu \& Kida, 2011; Samagwa, 2010; Mwakyonga, 2009). Sepsey (2010) observes that internal audit applied by local government does not fulfill its functions and in reality it does not contribute to the proper, regulated, economical, efficient and effective financial management of local governments. In the majority of local governments, internal audit has a systemic attitude, which consistently fails to assess and to develop the effectiveness of the financial management and controlling procedures of local government.

Moreover, a study by Kagashe (2008) reveals that many aspects including lack of management support mostly contribute to inefficiency and ineffectiveness of internal audit unit. This also proved by Kunze (2010) when assessing the impact of organisation structure on Internal Audit function in public organisation in Tanzania. Her concern is on the clear line of the reporting system of the findings to the same management that perform the duties as a result cause internal audit unit to be underutilised.

Therefore, she reveals that management has seen internal auditors as enemies, thus, they are not ready to establish strong internal audit unit as required by the LAFM; hence, it is stambling block on internal audit functions. Azza (2012), when assessing the perceived effectiveness of the internal audit function in Libyan public enterprises, discovered that, IA in Libyan public enterprises is not perceived as value-adding or having the capacity to improve an organisations operations. IA may not play an important role in assisting organisations to minimise wastage, maximise employment levels, increase wage rates, and production levels, and minimise capital devaluation as much as possible under the circumstances. Likewise, to other studies, Gansberghe (2005) also 
examined the effectiveness of internal audit. According to his perspective, perceptions and ownership, organis ation and governance framework, legislation, improved professionalism, conceptual framework and resources are revealed as basic factors influencing internal audit effectiveness.

\section{THEORETICAL FRAMEWORK}

There are many theories that can guide this research such as agency theory, theory of inspired confidence, financial planning cycle theory, budgeting theory and cost analysis theory, but for the purpose of this research work, the study dwelled only on budgeting theory, the reason behind chosen this theory is because budgeting theory involves executive preparation, legislative review, modification, and enactment; budget administration and post audit and evaluation which go cognizance with the subject matter on study.

\section{Agency Theory}

Agency is a name given to the practice by which productive resources owned by one person or a group are managed by another person or group of persons (Millichamp \& Taylor, 2008). A general description of an agency relationship states that it is a contract under which one or more principals engage another person or persons as their agent (s) to perform some service on their behalf. To enable this performance, delegation of some decision making authority to the agent is needed (Jensen et al., 1976). This theory is extensively employed in the accounting literature to explain and predict the appointment and performance of external auditors. Agency theory provides a useful theoretical framework for the internal auditing function. The theory not only helps to explain and predict the existence of internal audit, but it also helps to explain the role and responsibilities assigned to internal auditors by the organisation, and that agency theory predicts how the internal audit function is likely to be affected by organisational change (Adams, 1994).

\section{Theory of Inspired Confidence}

The theory of inspired confidence (Theory of rational expectations) (Limperg, 1932) addresses both the demand and the supply for audit services. The demand for audit services is the direct consequence of the participation of third parties (interested parties of a company) in the company (for this case public sector). These parties demand accountability from the management, in return for their investments in the company. Accountability is realised through the issuance of periodic financial reports. However, since this information provided by the management may be biased, and outside parties have no direct means of monitoring, an audit is required to assure the reliability of this information. With regard to the supply of audit assurance, Limperg (1932) suggests that the auditor should always strive efficiently to meet the public expectations.

\section{Financial Planning Cycle Theory}

Effective financial management requires the application of planning and analytical techniques to accommodate the risk and uncertainty that are inevitable in future-oriented decisions. Risk is taken no matter what the decision; even the decision to do nothing involves the risk of lost opportunity. An effective financial manager, whether in the public or private sector, must be aware of how opportunity, innovation, and risk are interrelated and must be willing to take risks appropriate to his or her level of responsibility where now the presence of internal auditors is so important (Steiss, and Nwagwu, 2014).

\section{Budgeting Theory}

A budget is a control mechanism to assure accountability, financial integrity, and legal compliance. A management tool to achieve operating economies and performance efficiencies; and a planning component to assess the overall effectiveness of government programs in meeting public service needs. Fiscal authority and responsibility can be delegated through the budget process while 
appropriate central control can be maintained. The budget process involves executive preparation, legislative review, modification, and enactment; budget administration and post audit and evaluation. The budget document should provide a clear and concise picture of both the programs to be carried out and the fiscal basis to support these activities (Steiss \& Nwagwu, 2014).

\section{Cost Analysis Theory}

No program decision is free of cost, whether or not it leads to the actual commitment of financial resources. An organisation is likely to encounter many different costs in choosing among alternative approaches to achieve its objectives. Costs include not only the expenditure of money, but also the consumption of physical resources, the employment of human resources, and the use of time. Factors that influence cost should be considered throughout the financial planning and management process in developing of plans and programs, in preparing budget requests, and after commitments have been authorised, in implementing programs or projects (Steiss \& Nwagwu, 2014)

\section{METHODOLOGY}

This study work employed the survey research design. The choice of the research design was to ensure that the data collected was used to determine the effect of internal audit on expenditure control in Mubi North Local Government Area. The population of the study consisted of the entire staff of the audit unit and finance department of Mubi North Local Government Area of Adamawa State. Since the study cannot cover the population due to factors like time, financial constraint and control over a large sample, the need for selection become ideal. From the population of the study 50 staff was selected as a sample for this study. The study employed simple random sampling technique because the method ensures that each item in the population have equal chance of being selected. The primary source of data was used. It involved the collection of data through the use of questionnaire and interview. The questionnaire was the main instrument of data collection. The questions were appraise the effect of internal audit on expenditure control. The questionnaire was administered to the employees in the local government audit unit and finance department in Mubi North local government area. The data for this project was collected, screened and tabulated. The techniques that were employed for the analysis of data indulged simple percentage and chi-square. The chi-square was used to test the formulated hypothesis in chapter one.

The chi-square is given by the formula

$$
\begin{aligned}
& \mathrm{X}^{2}=\frac{\left(\sum O-e\right)^{2}}{e} \\
& \text { Where: } \mathrm{O}=\text { observed frequency } \\
& \mathrm{e}=\text { expected frequency } \\
& \quad \Sigma=\text { summation }
\end{aligned}
$$

\section{ANALYSIS AND RESULTS Research Hypothesis}

The formulated hypothesis in chapter one states that "Internal audit has no

\begin{tabular}{|c|c|c|c|c|c|}
\hline \multicolumn{6}{|c|}{ The chi-square result is shown in table below } \\
\hline Responses & $\mathbf{O}$ & $\mathbf{E}$ & O-E & $(\mathrm{O}-\mathrm{E})^{2}$ & $\left.\frac{(\mathrm{O}-\mathrm{E})}{\mathrm{E}}\right)^{2}$ \\
\hline Strongly agree & 5 & 10.0 & -5 & 25 & 2.5 \\
\hline Agree & 4 & 10.0 & -6 & 36 & 3.6 \\
\hline Undecided & 2 & 10.0 & -8 & 64 & 6.4 \\
\hline Disagree & 19 & 10.0 & 9 & 81 & 8.1 \\
\hline Strongly disagree & 20 & 10.0 & 10 & 100 & 10.0 \\
\hline Total & 50 & & & & 21.6 \\
\hline
\end{tabular}
significant effect on expenditure control in Mubi North LGA". The chi-square statistics was used to test the hypothesis.

The chi-square calculated $=21.6$

Df $=(r-1) 5-1=4$

Chi-square critical value at $5 \%(4 \mathrm{df})=$ 7.815 at $5 \%$

Decision: Since the chi-square calculated of 21.6 is less than the critical table value of 7.815 , it is concluded with respect to the research hypothesis that internal audit has a significant effect on expenditure control in Mubi North LGA. 


\section{FINDINGS OF THE STUDY}

The following findings were derived from the above data analysis;

i.Finding revealed that internal audit in Mubi North LGA is very ineffective. This is because internal audit is not carry out effectively in the LGA.

ii. There is low level of compliance with expenditure guidelines in Mubi North LGA; this is because appropriates action are not by the top management of the Local Government Area for non-compliance.

iii. Internal audit has significant effect on expenditure control in Mubi North local LGA.

iv. Among the factors militating affecting the effectiveness of internal audit in Mubi North LGA, low quality of staff is the most importance factor.

\section{CONCLUSION}

Based on the summary of the major findings arrived at after analyzing the responses received from the respondents, the internal audit units plays important role in the control of expenditure in the Mubi North local government. Specifically:

i. The internal audit in Mubi North LGA is very ineffective.

ii. There is low level of compliance with expenditure guidelines in Mubi North LGA.

iii. Internal audit has significant effect on expenditure control in Mubi North LGA.

iv. Low quality of staff is the most important factor militating effectiveness of internal audit in Mubi North LGA.

\section{RECOMMENDATIONS}

The following recommendations are provided based on the findings and conclusions reached by the study:

i.There is need for top management of LGA to give high priority to internal audit, by putting in place strategies that will lead to effective practice of internal audit among the staff of the LGA which in turn will lead to effective expenditure control.

ii. There is need for management of the LGA to adhere strictly and impose discipline to all staff that refuses to comply with the expenditure guidelines in the LGA. This will go a long way to ensure compliance of expenditure guideline and control.

iii. There is need to make internal audit an autonomous department that will report to the legislature than the LGA executive. This will give room for more effective and of internal audit.

iv. There is need for internal audit department to employ competent staff in terms of educational qualification and work experience that will help in promoting internal audit in the LGA.

\section{BIBLIOGRAPHY}

1. Acca, A. (2003). Internal Audit and International Review. paper 2.6. AccraGhana wpp books.

2. Adams M, (1994). Agency Theory and the Internal Audit, Managerial Auditing Journal, 9 (8), 8-12.

3. Adams, A. B. (2004). Introduction to local government administration. Lagos, A-Z books.

4. Adeniji, A. (2004). Auditing and investigation, Lagos, First published Value Analysis consult-(publishers).

5. Anyakwu, M. A. (2010). Canon of Public Sector Accounting. Jos, G-Taf press Ltd.

6. Aqaisua, D. (2004). Practical Auditing and Investigation, Bayaro International Journals of Accounting Research, 1(1). 1114.

7. Azza, A.W. (2012). Perceived effectiveness of the internal audit function: A case study Libyan public enterprises.

8. Badara, S. (2012). The Role of Internal Auditors in Ensuring Effective Financial Control at Local Government Level: A case of Alkaleri LGA, Research Journal Finance and Accounting, 3 (4), Nigeria.

9. Dandago, K. I. (2002). Auditing in Nigeria: Comprehensive text, $2^{\text {nd }}$ edition Adamu, Kano. Joji publishers.

10. Jensen, M. \& Meckling, W. (1976). Theory of The Firm: Managerial Behaviour, Agency Cost, and Ownership Structure. Journal of Financial Economics, 3, 305360.

11. Kagashe, D. B. (2008). Thesis on effectiveness of the internal audit service unit in safeguarding public resources in 
Local Authorities: A case of Kibaha District Council, Unpublished MBA Thesis, Mzumbe University.

12. Kagashe, D. B. (2008). Thesis on effectiveness of the internal audit service unit in safeguarding public resources in Local Authorities: A case of Kibaha District Council, Unpublished MBA Thesis, Mzumbe University.

13. Kunze, D. K. (2010). Assessment of the impact of organization structure on Internal Audit functions in public organisation in Tanzania-Unpublished Msc (A\&F) Thesis, Mzumbe University.

14. Limperg, T. (1932). Theory of Inspired Confidence. University of Amsterdam.

15. Messier, W. F. (2003). Auditing and Assurance Service A Systematic Approach, $3^{\text {rd }}$ edition: Mc Graw-Hill/Irwin.

16. Mulinda, R. R. (2010). The role of Internal Auditing in Risk management: A case of Muhimbili National Health. Unpublished Msc (A\&F) Thesis, Mzumbe University.

17. Mwakyonga, L. S. (2009). The assessment of effectiveness of auditing in non-profit organizations: A case of Institute of Adult Education, Unpublished MBA Thesis, Mzumbe University.

18. Noorvee, L. (2006). Evaluation of the effectiveness of internal control over financial reporting. Published thesis of masters in economic, University of Tartu.
19. Okon, E. (2003). Local Government Administration in Nigeria, Uyo: M E F (Nigeria) LTD first published.

20. Okoya, J. O. (2004). Advanced Public administration, Enugu by macmillan publish.

21. Ray, D. \& Pary, G. (2001). Internal Audit Guidance: New York, Mc Graw-Hill.

22. Samagwa, A. M. (2010). Improving Internal Audit function efficiency for effectiveness risk management control in the Government Agencies: A case of TPSC. Unpublished Msc (A\&F) Thesis, Mzumbe University.

23. Sepsey, T. (2010). Internal Audits at Local Governments Audit Experiences of the State Audit Office of Hungary.

24. Steiss, A. W. \& Nwagwu, C. O. C. (2014). Financial Planning and Management in Public Organizations. www-personal. umich.edu/ steiss/page4.htm accessed 15/12/2020;11:30 a.m

25. Unegbu, A. \& Kida, M. (2011). Effectiveness of Internal Audit as Instrument of improving public sector Management. Journal of Emerging trends in Economics and Management Science 2 (4): 304-309, Nigeria.

How to cite this article: Babbuli Ibrahim Mohammed. Effect of internal audit on expenditure control in Mubi North Local Government Area. International Journal of Research and Review. 2021; 8(1): 48-58. 